\title{
TWO NEW SPECIES OF STREPTOCARPUS FROM SOUTHERN AFRICA
}

\author{
O. M. HILLIARD
}

An account of Streptocarpus was written for inclusion in Flora of Southern Africa; now that that publication has been suspended, two new names are validated here. The plants were discussed under $S$. rimicola in Hilliard \& Burtt, Streptocarpus. An African plant study, 240-241 (1971).

Streptocarpus makabengensis Hilliard, sp. nov. S. rimicolae Story affinis sed foliis utrinque glanduloso-puberulis (nec eglandulosis nec pilosis), ovario minute glanduloso-puberulo pilis patentibus (nec pilis ascendentibus $\pm 0.25 \mathrm{~mm}$ longis aliis glandulosis aliis eglandulosis) distinguenda.

Type: Transvaal, Pietersburg distr., Makabengberg, cult. RBG Edinburgh, C3864, from seed sent by G. McNeil (holo. E).

This species is known only from the Makabengberg, south of the Blaauwberg in the north-western Transvaal, where Messrs. Clifford Thompson and Gordon McNeil found it in 1961, growing under rock outcrops. It is allied to S. rimicola, currently recorded only from the Waterberg. The plant has only one or two leaves, beetroot-red below, the colour being retained in cultivation; the leaves of $S$. rimicola only occasionally develop a red flush. Streptocarpus makabengensis is further distinguished by its very short glandular hairs (no eglandular ones are present), which occur even on the upper surface of the leaf, an unusual feature in Streptocarpus. The hairs on the ovary are patent, not upward-pointing as in S.rimicola. In other respects, the flowers of the two species resemble one another.

Streptocarpus occultus Hilliard, sp. nov., aff. S. rimicolae Story sed habitu perenni (nec monocarpico), corollae tubo extra glanduloso-piloso pilis nonnullis $0.75-1.5 \mathrm{~mm}$ longis (nec parce glanduloso-pubescente pilis ad $0.5 \mathrm{~mm}$ longis) intus glabro (nec superne barbato), filamento ad connectivum dentifero (nec edentifero), antheris dorso pilis longis paucis praeditis (nec glabris), stigmate inaequaliter (nec aequaliter) bilabiato differt.

Type: Transvaal, Ermelo-Carolina district boundary, 9 miles from Warburton P.O. on Mbabane road, 5600ft., Hilliard 4774 (holo. E).

Like S. rimicola and S. makabengensis, S. occultus grows in the shelter of rock outcrops, and is known from only one site in the south-eastern Transvaal. Unlike its two allies, it is perennial. It differs further from S. rimicola in several floral characters: corolla tube with longer glandular hairs outside, no beard on the roof of the corolla tube, filaments toothed at their junction with the connective, anthers bearded on the back, and an unequally two-lipped stigma. Streptocarpus makabengensis may produce a minute rounded projection at the apex of the connective, but the corolla tube is only minutely glandular-puberulous outside, the roof is bearded, and the stigma is equally two-lipped. 